
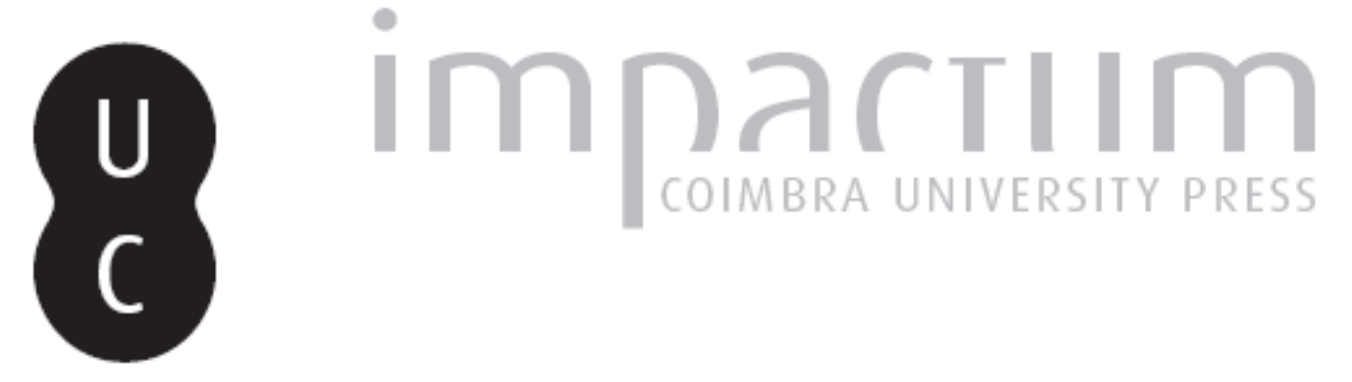

\title{
A intervenção política e governativa de Domingos Leite Pereira durante a Primeira República (1910-1926)
}

\author{
Autor(es): Leal, Pedro Figueiredo
}

Publicado por: Imprensa da Universidade de Coimbra

URL persistente:

URI:http://hdl.handle.net/10316.2/43336

DOI:

DOI:https://doi.org/10.14195/1645-2259_17_12

Accessed : $\quad$ 26-Apr-2023 12:05:27

A navegação consulta e descarregamento dos títulos inseridos nas Bibliotecas Digitais UC Digitalis, UC Pombalina e UC Impactum, pressupõem a aceitação plena e sem reservas dos Termos e Condições de Uso destas Bibliotecas Digitais, disponíveis em https://digitalis.uc.pt/pt-pt/termos.

Conforme exposto nos referidos Termos e Condições de Uso, o descarregamento de títulos de acesso restrito requer uma licença válida de autorização devendo o utilizador aceder ao(s) documento(s) a partir de um endereço de IP da instituição detentora da supramencionada licença.

Ao utilizador é apenas permitido o descarregamento para uso pessoal, pelo que o emprego do(s) título(s) descarregado(s) para outro fim, designadamente comercial, carece de autorização do respetivo autor ou editor da obra.

Na medida em que todas as obras da UC Digitalis se encontram protegidas pelo Código do Direito de Autor e Direitos Conexos e demais legislação aplicável, toda a cópia, parcial ou total, deste documento, nos casos em que é legalmente admitida, deverá conter ou fazer-se acompanhar por este aviso.

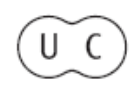




\section{A intervenção política e governativa de Domingos Leite Pereira durante a Primeira República (1910-1926) \\ The political and governmental intervention of Domingos Leite Pereira during the First Republic (1910-1926)}

\section{Pedro Figueiredo Leal}

Mestre em História Contemporânea (FLUL)

tabacaria@sapo.pt

Texto recebido em/Text submitted on: 25/11/2016

Texto aprovado em /Text approved on: 25/02/2017

Resumo: Domingos Leite Pereira foi um dos políticos mais importantes da República no ciclo que se seguiu à I Guerra Mundial. Neste tempo marcado por grandes dificuldades sociais e instabilidade política, foi presidente de três governos e ministro de dez. Disputou, especialmente contra António Maria da Silva, a liderança do Partido Republicano Português (PRP), então dominante, mas afectado pelo afastamento do seu líder histórico Afonso Costa. Falhou nesta disputa mas ganhou o reconhecimento geral da classe política pelo papel conciliador que desempenhou enquanto presidente da Câmara dos Deputados, de tal modo que foi a única personalidade aceite para formar o Governo que realizou as últimas eleições da República, em 1925.

Palavras-chave: Domingos Leite Pereira, Primeira República, Partido Republicano Português, História Contemporânea, Política.

Abstract: Domingos Leite Pereira was one of the most important politicians of the First Republic after the First World War. In this period marked by great social difficulties and political instability, he was president of three governments and minister of ten. He fought, specially against António Maria da Silva, for the leadership of the Portuguese Republican Party (PRP), then dominant, but affected by the retreat of his historical leader Afonso Costa. He lost this fight but gained general approval of the appeasing role he plaied as president of the Chamber of Deputies, so that he was the only one able of forming a government that held First Republic last elections in 1925.

Keywords: Domingos Leite Pereira, First Republic, Portuguese Republican Party, Contemporary History, Politics.

\section{A intervenção política e governativa de Domingos Leite Pereira durante a Primeira República (1910-1926)}

Durante a I República, Domingos Leite Pereira foi o político que mais tempo ocupou funções ministeriais, participando em dez governos e presidindo a três deles. Foi também o único chefe do governo a organizar duas eleições legislativas $(1919,1925)$. Para além disso, foi o Presidente da Câmara dos Depu- 
tados que mais tempo ocupou o lugar. Deputado desde a Assembleia Nacional Constituinte, foi também ministro e líder de uma facção dissidente do Partido Republicano Português (PRP).

Apesar do seu extenso currículo, o percurso político de Domingos Pereira tem merecido pouca atenção por parte da historiografia. Na obra As Constituintes de 1911 e os seus Deputados é-lhe feita uma breve referência biográfica. A Grande Enciclopédia Portuguesa e Brasileira definiu-o como "político, parlamentar e jornalista", orador "brilhante" que prestigiou as "instituições que serviu, algumas vezes em circunstâncias graves e difíceis"; destacou o seu papel como Presidente da Câmara dos Deputados, que conquistou o "respeito dos parlamentares de todas as correntes e adquiriu dedicações, até da parte dos adversários políticos", e como Ministro dos Negócios Estrangeiros, que encetou uma acção "notável" nas "negociações tendentes a restabelecer a boa harmonia entre Portugal e o Vaticano" (vol. XXI: 130-131). No Dicionário de História de Portugal, David Ferreira realçou a chefia do seu primeiro Governo, "num momento bastante difícil", em virtude da "agitação social e das lutas políticas" decorrentes do termo da Primeira Guerra Mundial e do "esmagamento das tentativas restauracionistas de Janeiro de 1919"; também destacou o seu papel na presidência da Câmara dos Deputados, "lugar onde, mercê da sua correcção e imparcialidade e do seu feitio conciliador, que não excluía firmeza nem perseverança, alcançou o respeito e a simpatia dos representantes de todas as correntes políticas existentes no Parlamento" (Ferreira 1968, Vol. III: 354). Foram referências sintéticas que justificaram que Oliveira Marques lembrasse, no seu Guia de História da $1^{a}$ República Portuguesa, que "outra importante figura da República que aguarda o seu biógrafo é Domingos Leite Pereira" (Marques 1981:490). Ao mesmo Oliveira Marques, bem como a António Ventura, ficou a dever-se o conhecimento do percurso maçónico deste republicano bracarense (Marques 1986, vol.2: 1110-1111; Ventura 2011:242-243). Os estudos mais recentes decalcaram, de modo geral, o que se apurou na Grande Enciclopédia Portuguesa e Brasileira e no Dicionário de História de Portugal (Reis 1985,I: 378; Marques 2000: 340-341). Em 2006, Carlos Jaca, na revista Fórum, publicou uma obra de divulgação, contendo bastantes informações obtidas pelo acesso a algum espólio familiar (Jaca 2006: 79-117) Na obra Os Presidentes do Parlamento Português - I República (1910-1926), António José Queiroz apresentou uma síntese inovadora incidindo no período em que Domingos Pereira exerceu a presidência da Câmara dos Deputados e durante a oposição ao Estado Novo (Sousa, Pereira 2012, II: 323-341, 385-399, 413-431) Mais recentemente, Ana Catarina Pinto elaborou um sumário da sua vida, no Dicionário de História da I República e do Republicanismo, pondo em evidência a sua acção governativa (Pinto 2014, vol. III: 244-246) 
O presente artigo pretende ser uma síntese da dissertação de mestrado do autor na qual se procurou desenvolver e contextualizar a intervenção política e governativa de Domingos Leite Pereira durante a I República (Leal 2014).

\section{Republicano desde jovem}

Domingos Pereira nasceu em 1882, em Braga. Em contraste com o ambiente conservador que caracteriza a sua cidade natal, destacou-se, quando era estudante, pela "propaganda republicana e anticlerical", desde "1900, por ocasião da questão religiosa” (As Constituintes... 1911:28). Ele mesmo recordou, mais tarde, que se convencera ser a República o mais "natural" dos regimes políticos, a forma constitucional do Estado que mais "facilmente e mais logicamente conduzia um povo à felicidade e à paz, ao bom entendimento entre os cidadãos de uma pátria, entre os povos de uma civilização" (Sol, 8.10.1949).

Em termos académicos, frequentou a Faculdade de Teologia, na Universidade de Coimbra, onde concluiu o bacharelato. A sua carreira prosseguiu como professor e jornalista, chegando também a frequentar, em Lisboa, o Curso Superior de Letras.

Desde cedo travou conhecimento com os líderes republicanos nacionais, como Bernardino Machado, António José de Almeida e Afonso Costa. Considerava este último a figura política de maior referência, o "homem mais bem dotado de autênticas qualidades de estadista" que conhecia. Se a sua obra havia falhado, "quem perdeu, verdadeiramente, foi o país". (O Diabo, 30.5.1937)

Em Braga, onde o movimento republicano era residual, empenhou-se fortemente, quer em comícios quer na criação de centros republicanos e na fundação de jornais, como $O$ Radical e $A$ Verdade. Não é, pois, de espantar que, após a implantação da República, Domingos Pereira fosse nomeado administrador do concelho de Braga, acumulando com a presidência da comissão administrativa municipal da cidade. Em 1911, tornou-se presidente do centro republicano distrital de Braga, sendo iniciado na Maçonaria. A partir de maio desse ano integrou a Assembleia Nacional Constituinte como deputado pelo círculo de Barcelos. Após a aprovação da nova Constituição, e da cisão que se seguiu no PRP, fez parte do grupo parlamentar democrático, afeto a Afonso Costa.

Sob a liderança de Afonso Costa, o PRP (também conhecido como Partido Democrático), controlando a máquina eleitoral e as autoridades administrativas, manteve a hegemonia na vida política portuguesa e foi um dos principais responsáveis pela entrada de Portugal na I Guerra Mundial (Teixeira 1996). O agravamento das condições de vida no país, em consequência da participação no conflito, esteve na origem da revolução chefiada por Sidónio Pais, em Dezembro de 1917, que motivou o exílio de Afonso Costa. Durante o consulado «sido- 
nista» (até Dezembro de 1918), Domingos Pereira, como muitos membros democráticos, passou por privações e chegou a ser detido.

\section{Ministro e chefe de vários governos}

Domingos Pereira fez parte da nova geração de líderes republicanos que assumiram o poder após a I Guerra Mundial (Meneses 2004: 421-446). As amplas transformações políticas e sociais do pós-guerra marcaram o fim de actuação da primeira linha de líderes como Afonso Costa, António José de Almeida e Brito Camacho. Assistiu-se então à emergência, no caso do PRP, de novas figuras como António Maria da Silva, Álvaro de Castro, José Domingues dos Santos e Domingos Pereira (Farinha 2009 $: 463-484$ ).

A ascensão governativa de Domingos Pereira, como Damião Peres salientou, numa das primeiras histórias gerais da I República, era "um sinal dos novos rumos que ia tomar a República Velha”; na opinião desse historiador, Domingos Pereira era "vulto democrático irrelevante na política" antes de integrar o governo de José Relvas, "mas [...] doravante ia passar a figurar entre os grandes do seu partido" (Peres 1954: 220).

O princípio do ano de 1919 marcou a transição do regime sidonista, que não conseguiu sobreviver à morte do seu fundador. Embora fragilizado, o PRP (diga-se, da maioria dos republicanos) definiu como prioridade o combate à insurreição monárquica que deflagrara no norte do país. Era esse o caminho para o seu regresso pleno ao poder. Por isso, aceitou integrar, de forma cautelosa, o ministério de concentração chefiado por José Relvas (que incluía ainda os sidonistas), com a entrada de figuras secundárias, como Domingos Pereira na pasta da Instrução. Ao apreciar o novo Governo, $O$ Mundo fixava a sua atenção em Domingos Pereira: embora não se tratasse ainda de uma figura de "primeiro plano", constituía "aquela boa reserva de gente nova, sem impaciência de ambições de curta data" (O Mundo, 2.2.1919).

Com o inequívoco apoio e o forte patrocínio deste jornal, dirigido por Carlos Trilho, que se tornaria seu órgão oficioso, o novo ministro começou rapidamente a ganhar notoriedade, especialmente junto dos professores do ensino primário, através do aumento dos respectivos salários. Para o seu mandato, apresentou três desígnios: "contribuir para a conciliação nacional", "enérgica defesa do regime e, ao mesmo tempo, o mais aberto espírito de tolerância" (O Mundo, 2.2.1919).

A vitória das forças republicanas sobre a "Monarquia do Norte" fez cessar o frágil equilíbrio que sustentava a governação. Logo começaram a ser ouvidos, em comícios e manifestações, apelos ao saneamento do Estado, expurgando-o dos elementos nocivos (os monárquicos e os sidonistas) ao regime republicano. Este movimento reivindicativo, de que o Mundo se tornou o porta-voz, ultrapassou rapidamente os propósitos moderados de José Relvas, que desejava reformular o 
sistema politico através de uma alternância bipartidária entre o PRP e elementos conservadores. $\mathrm{O}$ chefe do Governo queria evitar que os Democráticos voltassem a monopolizar o poder com risco de levar a uma nova revolução. Contudo, foi obrigado a transigir com o radicalismo, entrando numa ditadura administrativa após a dissolução das câmaras parlamentares sidonistas. E, vendo-se sem apoios, não tardou a pedir a demissão.

Enquanto os vários partidos se digladiavam no acesso ao poder, Domingos Pereira actuava em dois planos, quer colocando-se na vanguarda das aspirações revolucionárias que exigiam a depuração completa do novo regime restaurado, quer procurando meios de consenso com as outras forças partidárias. A sua cordialidade e um feitio conciliador, sem prejuízo de ser firme na defesa da República, foram fundamentais para congregar apoios entre as fações quer moderadas quer radicais. Quando as posições começaram a extremar-se e perante o perigo de uma deriva revolucionária, acabou por surgir, naturalmente, como uma solução de compromisso, entre os vários partidos, na chefia de um novo Governo.

Por ser relativamente desconhecido, Domingos Pereira, que ocupava também a pasta do Interior, pôde apresentar-se perante a população, nomeadamente o operariado, como um "político republicano que ainda não estava queimado", recordaria Alexandre Vieira, diretor de A Batalha (Vieira 1950: 112). O Século chamava-lhe um Governo de "jovens" (1.4.1919), já que a maioria dos seus membros tinha menos de 40 anos, sem qualquer experiência governativa.

Excluídos os Sidonistas, o executivo foi constituído por Democráticos, Evolucionistas, Unionistas e um Socialista. Pretendia ser como que uma emulação do Governo Provisório da República, procurando refundar o regime e encetar uma vasta legislação reformadora. Mas ao controlar o Ministério do Interior, garantia desde logo ao PRP a vitória nas eleições seguintes.

A defesa do regime perante novas insurreições tornava-se prioritária, sendo, pois, reorganizadas as forças policiais. Esperava-se que a Guarda Nacional Republicana (GNR), dotada de um significativo aumento de efetivos e armamento, servisse como um contrapoder a qualquer levantamento reacionário por parte do Exército, mas também como uma barreira às reivindicações do operariado.

Esses meses foram, de facto, marcados por grande agitação social. Por toda a Europa surgiram, depois da guerra, movimentos a reivindicar melhores condições de vida, maior redistribuição dos bens e da riqueza e um papel mais interventivo dos governos na proteção dos trabalhadores e dos mais carenciados. As revoltas alastravam, influenciados pela experiência soviética. Perante tal agitação, os governos enveredaram por uma política de cedências, tentando captar o operariado.

Em entrevista, Domingos Pereira reconhecia a necessidade de se ir ao "encontro das justas reivindicações do proletariado", para se evitar que "pela desordem permanente, venhamos a dar ao mundo a ideia de um povo de convul- 
sionários" (O Mundo, 12.4.1919). O Governo funcionava em ditadura administrativa, continuando a utilizar as leis de exceção, aprovadas no início da guerra, que lhe conferiam faculdades legislativas especiais, até às eleições. Para o setor mais radical que tentava tutelar a ação governativa, a total republicanização do Estado - envolvendo o saneamento e julgamento dos revoltosos monárquicos, a depuração do Exército e a institucionalização dos revolucionários civis - seria bastante prejudicada se o sistema se normalizasse do ponto de vista parlamentar, abandonando o seu caráter revolucionário.

Mesmo depois das eleições, porém, o Governo continuou a legislar ao abrigo das leis de exceção, promulgando, em sucessivos suplementos, quase mil decretos assinados com a data da véspera do ato eleitoral, 10 de Maio. Como explicaria Cunha Leal, tratava-se de uma "ditadura disfarçada, feita por bons republicanos, em especiais circunstâncias", significando a "necessidade de fazer, naquele dia, trabalho que o Parlamento levaria meses ou talvez anos a fazer" (Leal 1926: 184-185).

Parte destes decretos concretizaram, por intermédio do ministro socialista do Trabalho, uma intensa legislação social, abrangendo a delimitação do horário de trabalho, a criação dos seguros sociais obrigatórios em casos de doença, desastres no trabalho, invalidez, velhice e sobrevivência; a construção de bairros sociais; a organização das bolsas sociais de trabalho, a fundação do Instituto de Seguros Sociais Obrigatórios e de Previdência Geral (Pereira 2012: 320-344). Outros decretos remodelaram ministérios e criaram direções-gerais, repartições e institutos, permitindo a entrada massiva de milhares de funcionários, acarretando uma excessiva responsabilidade financeira para o Estado. Para os partidos, em especial o PRP, este processo foi fundamental para voltar a dominar as suas redes clientelares com prebendas, cargos e sinecuras, como forma de pagar favores, agremiar votos, ganhar eleições e sustentar-se no poder. Os suplementos do Diário do Governo com a data de 10 de Maio de 1919 ficaram associados ao nome de Domingos Pereira e a todo o regime, simbolizando mais uma política despesista e devorista do que propriamente uma política percursora de um Estado Social (Wheeler 1985: 179-186; Telo 1980, I: 113-125).

As eleições, realizadas em 11 de Maio de 1919 e marcadas por uma elevada abstenção, deram uma vitória esperada ao PRP (Lopes 1994:137-152), permitindo-lhe reafirmar a sua hegemonia na vida política. Todavia, dada a ausência do seu líder histórico, Afonso Costa, o partido entrou numa intensa disputa pela sua liderança, o que veio condicionar de forma decisiva a ação politica, a formação e duração dos governos nos anos seguintes. Álvaro de Castro e António Maria da Silva destacaram-se desde logo neste confronto; mas o capital e a notoriedade que Domingos Pereira começava a receber, aliados a uma intensa propaganda encetada pelo Mundo, conferiam-lhe também para tal fortes possibilidades. Neste contexto, a nova bancada parlamentar do partido fragmentou-se 
em diversas fações, não dando ao Governo suficiente confiança, donde este foi substituído por outro, presidido pelo coronel Sá Cardoso. Assim Domingos Pereira cedeu a chefia do Governo, mas no mês seguinte, em Julho, foi eleito Presidente da Câmara dos Deputados e, em Outubro, passou a integrar o Diretório do PRP.

O Governo Sá Cardoso, embora constituído integralmente por membros do PRP e detendo uma maioria numérica no Parlamento, não resistiu mais do que sete meses. Nas suas memórias, Alberto Xavier, chefe de gabinete de Sá Cardoso, denunciou uma "surda luta de ambições e de rivalidades pessoais sem grandeza" (Xavier 1950:63). De facto, a estratégia das várias facções rivais passava por impedir que qualquer uma conseguisse preponderar e consolidar-se no poder, preferindo condicionar e boicotar a sua actividade parlamentar e governativa, anulando-se mutuamente, neutralizando, deste modo, a maioria absoluta que $o$ PRP dispunha.

Assim dividido, este partido dominante não impediu a eleição presidencial de António José de Almeida, oriundo do minoritário Partido Evolucionista; nem impediu a aprovação de uma alteração constitucional no sentido de atribuir ao Presidente da República o poder de dissolução parlamentar, permitindo-lhe oferecer a outro partido a possibilidade de organizar e vencer novas eleições, quebrando o círculo em que o mesmo partido praticamente monopolizava o poder.

Por outro lado, a GNR, fortemente armada, adquiriu um autêntico poder moderador, capaz de interferir na formação dos governos (Palacios Cerezales 2011: 244-254). Assim aconteceu, em Janeiro de 1920, quando, em substituição do Governo Sá Cardoso, o Presidente da República convidou o Partido Liberal, recém-nascido da fusão entre Evolucionistas e Unionistas. Era a primeira tentativa de fazer rodar o poder fora do PRP, o que suscitou uma manifestação hostil, promovida pelas bases republicanas radicais. Então a GNR, sob o comando de Liberato Pinto, mostrou-se neutra, abstendo-se de utilizar a sua grande capacidade militar para reprimir os protestos; de tal modo que o Governo indigitado, percebendo que não dispunha do seu apoio, não chegou a tomar posse.

Perante o impasse, Domingos Pereira foi pela segunda vez chamado a formar Governo. Pretendia formar um governo de união republicana com membros de todos os partidos, no sentido de neutralizar a grande tensão politica. E após demoradas negociações, conseguiu apresentar um executivo com membros do PRP, do Partido Liberal e um socialista, deixando na oposição apenas o pequeno Grupo Popular de Cunha Leal. Contudo, os próprios partidos que compunham o executivo mostravam bastantes reservas na solução política encontrada, demostrando assim a instabilidade permanente que marcaria estes anos (Peres 1954: 261-267).

Os tempos eram diferentes do seu primeiro Governo que promulgara tão vasta legislação. $\mathrm{O}$ agravamento da crise económica e financeira nestes anos do 
pós-guerra refletiu-se no crescimento exponencial da dívida pública, na forte inflação, na desvalorização da moeda, no aumento da circulação fiduciária e num grande défice na balança comercial; o aumento dos salários não acompanhava o do custo de vida (Medeiros 1978; Telo 1980, I).

$\mathrm{Na}$ apresentação parlamentar, Domingos Pereira considerou que o seu programa seria "aquele que as condições atuais do país permitam realizar"; procurava alcançar a mais "rigorosa economia dos dinheiros do Estado", com várias medidas, tais como: a retoma da "lei travão", a remodelação dos serviços públicos e um maior poder de veto ao ministro das Finanças para a contenção de despesas (Diário da Câmara dos Deputados (DCD), sessões de 3 a 5.2.1920). Mas à semelhança do Governo anterior, Domingos Pereira esteve sempre condicionado por uma atitude desafiante e indisciplinada por parte de um número significativo de deputados do seu próprio partido, sob a influência de António Maria da Silva, que não lhe escondia a sua hostilidade. Durante um debate parlamentar, quando se discutiam despesas exorbitantes nos vários ministérios, António Maria da Silva lançou, em aparte, uma frase que seria muito glosada: "isto é um país que tem estado a saque (Peres 1954: 265-266)

Em março, confrontado com um forte movimento grevista que incluía ferroviários, funcionários públicos, Correios e Telégrafos, Domingos Pereira tentou que o Parlamento aprovasse medidas punitivas sobre os funcionários grevistas. Mas como as suas propostas fossem rejeitadas por elementos do seu próprio partido ( $D C D, 4.3 .1920)$, não lhe restou outra opção senão pedir a demissão.

\section{Dissidente}

A queda do Governo fez avançar as fações internas rivais do PRP. Contudo, quer António Maria das Silva quer Álvaro de Castro viram goradas as suas tentativas para formar um novo executivo, devido a bloqueios mútuos. Álvaro de Castro rompeu definitivamente com o partido, fundando um novo agrupamento: $\mathrm{o}$ Partido Reconstituinte (Silva 1996).

Refletindo sobre estes acontecimentos, Domingos Pereira reconheceu o que podia ser considerado como o "fracasso do próprio Partido Democrático", e até, de certo modo, o "fracasso da própria República". Isso devia-se, segundo ele, à falta de "juízo" e por não haver, "entre os republicanos, nem dentro dos partidos, a ordem, o entendimento, a disciplina necessárias" (A Capital, 9.3.1920). Permaneceu no partido, em conflito aberto com António Maria da Silva, mas era este, como salientava a imprensa, quem parecia assegurar o "grosso do partido" (A Capital, 4.2.1920).

Em Novembro, o frágil equilíbrio que sustinha o PRP acabou por se quebrar quando Álvaro de Castro foi convidado a formar Governo e a direção do partido lhe recusou apoio. Domingos Pereira abriu uma dissidência, acompanhado 
por vários deputados, e integrou o novo executivo como ministro dos Negócios Estrangeiros.

Os membros dissidentes esperavam que muitos outros membros do PRP seguissem os seus passos, isolando António Maria da Silva. Mas essa "esperança" redundou em "autêntico fracasso", conforme recordaria Cunha Leal nas suas memórias (Leal 1967, II: 252). E sem maioria parlamentar, o Governo de Álvaro de Castro caiu em poucos dias. Apesar do apoio oficioso do Mundo, a maior parte das comissões democráticas manteve-se fiel à sua direção. Quanto à dissidência de Domingos Pereira, limitada a cerca de quinze deputados e sem grande impacto na vida política, resignava-se a um modesto papel parlamentar.

A grande vitória de António Maria da Silva assegurava-lhe o maior número do grupo parlamentar e dos órgãos dirigentes, bem como o uso dos recursos disponibilizados ao maior partido com acesso ao poder. Para além disso, dispunha de uma grande ligação às bases que o seu cargo de administrador-geral dos Correios e Telégrafos, um dos maiores órgãos empregadores do país, ajudava a sustentar.

Em representação do seu Grupo Dissidente, Domingos Pereira participou no Governo que se seguiu, em Novembro de 1920, liderado por Liberato Pinto, o poderoso comandante da GNR. Perante a desagregação partidária, a Guarda Republicana assumia plenamente o papel de salvaguarda do regime, embora o seu crescente poder também começasse a infundir receio na classe política. Apesar da forte expetativa que gerou, foi este mais um Governo que poucos meses durou; e Liberato Pinto não tardou a ser exonerado do cargo de chefe de estado-maior, acusado de concussão (Santos 1999: 220-226).

Domingos Pereira tornou a participar no Governo seguinte, em março de 1921, presidido por Bernardino Machado, que integrava todas as fações e dissidências do PRP. Mas também este Governo caiu, dois meses depois, perante uma sublevação de tropas da GNR, inconformadas com a queda do seu comandante.

Então, o Presidente da República tentou outra vez uma solução fora do PRP dominante - com a anuência de António Maria da Silva, que pretendia liquidar as dissidências - entregando o Governo a Tomé de Barros Queiroz, do Partido Liberal, a quem concedeu também, pela dissolução parlamentar, a faculdade de organizar as eleições. O Grupo de Domingos Pereira procurava desenvolver a sua estrutura animando assembleias e organizando comissões, mas sem conseguir implantar-se no país, pelo que, nas eleições de Julho de 1921, apenas elegeu quatro deputados.

Pela primeira vez os Democráticos não ganhavam uma eleição (sem contar com a de 1918, do regime de Sidónio, à qual não concorreram). Mas o Partido Liberal, dividido entre ex-unionistas e ex-evolucionistas, não aproveitou a vitória para se tornar uma sólida alternativa de direita. Em agosto, ainda dentro do Partido Liberal, a chefia do Governo passou para António Granjo, da fação evolu- 
cionista. Mas em diversos meios fermentava uma conspiração para derrubar este Governo, que se tornou alvo de todos os ataques (Silva 1996: 273-283; Farinha 2009:104-107).

O regresso de Afonso Costa à chefia de um governo de salvação nacional republicana era, para muitos e em particular para o Grupo de Domingos Pereira, a solução messiânica do impasse. Todavia, Afonso Costa vira o seu nome comprometido no escândalo dos 50 milhões de dólares, resultado da negociação de um empréstimo financeiro internacional que se revelaria uma enorme burla. Tentando desesperadamente defender o antigo tribuno republicano, o Mundo atacava com uma violência cada vez maior o Governo de António Granjo, focando especialmente os interesses religiosos e monárquicos a que ele estaria sujeito, acirrando ainda mais as bases revolucionárias, espalhadas pela Marinha, a GNR e vários centros republicanos de Lisboa (Peres 1954: 305-311: Meneses 2010: 127-146).

A hostilidade acentuou-se com a condenação de Liberato Pinto a um ano de inatividade num quartel, por prática de atos comerciais inconciliáveis com as suas funções militares. E culminou na revolução de 19 de Outubro de 1921, promovida por elementos da GNR e da Marinha, e nos assassinatos de António Granjo e dos «fundadores da República», Machado Santos e José Carlos da Maia. (Pábon 1951: 539-573).

Perante o desfecho sangrento e após a tomada de poder pelas forças revoltosas, Domingos Pereira surgiu como um elo de consenso: usando da sua influência, auxiliou o Presidente da República a formar uma barreira contra os mais radicais, através de um Governo de transição que procurou devolver o regime à normalidade constitucional. A sua atitude foi amplamente elogiada pela imprensa, inclusive pelo República, afeto a António Granjo, que o considerou um "ilustre homem público que sempre soube fazer política com correção e lealdade, pelo que conta em todos os seus próprios adversários verdadeiros amigos pessoais" (República, 10.12.1921).

\section{Conciliador}

Domingos Pereira e a maioria dos membros dissidentes regressaram ao PRP, após a "Noite Sangrenta", sob o clima de reconciliação. Na sua opinião, a solução do problema político português passava por "todos" os cidadãos colocarem de parte "egoísmos, vaidades e ambições". Que todos se unissem, abatessem "bandeiras partidárias", esquecessem "divergências doutrinárias, ódios pessoais, rivalidades”. Só desse modo seria possível fazer frente, como uma muralha, "à onda formidável de indisciplina geral, de horrível agitação que está dissolvendo a nação". Fazia questão de se afirmar também como um "conciliador": era de conciliação que o país necessitava para "abandonar de vez as revoluções" (O Século, 26.11.1921). 
Em 1922, o regime entrou num relativo apaziguamento. António Maria da Silva assumiu a chefia governativa durante mais de um ano. Na oposição, assistiu-se à fusão do Partido Reconstituinte (de Álvaro de Castro) e do Partido Liberal, dando origem ao Partido Nacionalista. (Baiôa 2015). O Governo aliviou o défice do Estado, mas ao reduzir os efetivos e o armamento da GNR, quebrou o equilíbrio político e militar que esta organização fazia com o Exército. E o Exército, ao assumir doravante a sustentação do regime, passou a ser alvo de apelos cada vez mais frequentes e firmes para uma intervenção salvadora, inspirados nos regimes autoritários que Mussolini e Primo de Rivera iniciavam na Itália e na Espanha e que tanto iriam condicionar o futuro da Europa.

Domingos Pereira regressou à presidência da Câmara de Deputados. Procurou dignificar o papel das "instituições parlamentares", entendendo que "elas, por muito más que sejam, laborando, com todos os seus erros, são sempre superiores a qualquer governo pessoalista, a qualquer homem, por muito superior que seja" (Diário do Senado,7.8.1925). A isenção que revelou a conduzir os trabalhos parlamentares foi reconhecida por todas as bancadas, obtendo um inquestionável estatuto de imparcialidade, moderação e conciliação. Quando a atividade parlamentar estava cada vez mais desacreditada, Domingos Pereira fazia questão de lembrar que mais valia "um mau Parlamento que uma boa ditadura" (Diário de Lisboa, 23.10.1922).

Como ministro dos Negócios Estrangeiros, manteve uma política de reaproximação com a Santa Sé, que aliás vinha a ser seguida desde o sidonismo. Procurava especialmente cativar os católicos a integrarem-se no regime republicano, afastando-os da órbita monárquica. Em sua opinião, era um "erro" considerar que, "para se ser um bom republicano, se devesse ser agressivo para com a Igreja Católica” (DCD, 4.3.1926).

Em 1925, o regime republicano tornou a cair num impasse. E o maior responsável por isso era o PRP, partido dominante, que ajudava a derrubar no Parlamento sucessivos governos mesmo que fossem presididos por elementos seus, como Alfredo Rodrigues Gaspar, Vitorino Guimarães ou José Domingues dos Santos.

Este último executivo tentou enveredar por uma via mais socializante e reformista. Contudo, a prioridade passava agora por sobreviver politicamente a todo o custo, sem hostilizar demasiado a direita politica. Procurando compromissos mais ou menos desesperados, os governos seguintes tentavam enveredar por uma política de cedências em relação às forças vivas, às associações patronais, que tementes do radicalismo republicano, se reorganizavam, formando até associações que não hesitavam em intervir politicamente, como a União dos Interesses Económicos.

A tentativa do golpe de 18 de Abril de 1925 - que contou, pela primeira vez, com a intervenção de altas patentes do Exército - veio demonstrar, apesar de 
falhada, que os militares estavam cada vez mais inclinados a intervir na mudança das instituições.

Dentro do PRP assistia-se novamente ao confronto polarizado agora entre os "bonzos" de António Maria da Silva, e os "canhotos" de José Domingues dos Santos. O reacender desta luta pela liderança fomentou uma violenta "guerra civil" partidária, que mais agravou a crise do regime (Queiroz 2008).

Domingos Pereira tentava manter-se ao centro. No congresso partidário desse ano, pediu respeito para aqueles que, divergindo de "opiniões", não deveriam divergir de "princípios". Acima de tudo, devia preconizar-se a "defesa" e a "integridade" da República, a união de todos os republicanos: "não travemos lutas que cheguem às raias do ódio". Enfatizava que o partido não podia querer para si o "monopólio odioso e injustificado da salvação da República"; o regime "não podia viver com um só partido". Deste modo, e querendo deixar bem vincadas as palavras de "calma, justiça e de paz", condenava "todas as intolerâncias", apelando à cooperação de todos os "que honestamente queriam servir a República, até fora das fronteiras partidárias” (O Rebate; O Século, 9.6.1925). Ao analisar o congresso, o Diário de Lisboa assinalava que o discurso de Domingos Pereira tinha sido "incontestavelmente" o "mais elegante, mais ponderado, mais republicano" de todo o congresso, para além de conseguir os aplausos de todos os "grupos, de todas as correntes" (9.6.1925).

António Maria da Silva conseguiu assegurar a vitória no congresso, derrotando o seu rival, José Domingues dos Santos. Contudo, se conseguiu assegurar para si o controlo do Directório, permaneciam elementos hostis no próprio grupo parlamentar.

As eleições legislativas previstas para o final do ano teriam uma importância capital: quem organizasse e controlasse o processo eleitoral teria um papel decisivo na constituição das novas câmaras, na construção de uma maioria e no redimensionamento do espetro político. As forças que se opunham à liderança de António Maria da Silva, capitaneadas por José Domingues dos Santos, não poderiam permitir que fosse ele a ter esse papel; por isso ajudaram a derrubar o seu quarto Governo, menos de um mês depois de ele ser constituído.

Neste quadro, o próprio Presidente da República, Manuel Teixeira Gomes, ameaçou renunciar. Coube então a Domingos Pereira, como Presidente da Câmara dos Deputados, a tarefa de outra vez formar Governo. A concordância unânime que tinha adquirido nesse cargo, e o seu espírito de conciliação, permitiram-lhe ser o único elo de aceitação entre as várias correntes. Formou um novo ministério à base do PRP, incluindo quatro membros provenientes do gabinete anterior. Para António Maria da Silva não passava de um compasso de espera até regressar ao poder, depois das eleições, com uma nova maioria e um grupo parlamentar saneado da nova dissidência.

Entretanto, procedeu-se ao julgamento dos revoltosos do golpe de 18 de Abril. Desde as primeiras sessões, percebeu-se que, mais do que os revoltosos, 
era o próprio regime que estava a ser julgado. Acusados de se levantarem contra a "autoridade" do Presidente da República e dos "ministros do governo", e de incitarem "civis e militares" a saírem dos quartéis sem "ordem legal" (Chorão 2010: 76), os réus assumiram, com orgulho, as suas conviçcões e propósitos, não escondendo as suas intenções. Sem surpresa, os juízes absolveram-nos, dando como não provados os crimes. Assim mostraram que aquela revolta contra $o$ poder instituído não merecia sanção, mas sim um quase louvor; que qualquer nova revolta estaria sancionada e legitimada pelas altas instâncias militares. Foi um duro golpe para o Governo, acusado de nada ter feito para impedir a absolvição dos acusados. As conspirações militares continuaram, apertando o cerco ao regime e abrindo o caminho para a revolução de 28 de Maio do ano seguinte.

Quanto às eleições, os partidos não pouparam esforços na sua preparação e na mobilização dos eleitores. Seria a última tentativa de se efectuar uma alternância governativa por meios constitucionais. Domingos Pereira frisou que do Ministério do Interior se haviam dado "ordens de toda a espécie" para garantir "a todos a maior liberdade, a maior imparcialidade" (Diário de Lisboa, 3.11.1925). Não bastavam "as boas intenções", respondeu o órgão da União dos Interesses Económicos, pois ninguém ignorava como os "truculentos delegados do governo" desobedeciam "às ordens emanadas do Terreiro do Paço e se riem delas" (O Século, 7.11.1925). Na realidade, Domingos Pereira era um líder isolado; o seu Governo esteve sempre condicionado pela ação velada do Diretório do PRP, controlado por António Maria da Silva.

Apesar do seu desejo de pacificação, as eleições, realizadas no dia 8 de Novembro, foram marcadas por inúmeros atos de violência, manipulação e acordos eleitorais ilícitos e acusações de fraude, quer na votação, quer no apuramento de resultados (Baiôa 2015: 252-326; Queiroz 2008: 103-125). Confirmaram igualmente a hegemonia do PRP na vida política nacional. Cunha Leal, que então militava no Partido Nacionalista, diria nas suas memórias que, embora Domingos Pereira "fosse bem mais escrupuloso na sua orientação do que o seria António Maria da Silva", a "máquina eleitoral do PRP" "não poderia deixar de sair triunfante desta compita política” (Leal 1967, II: 443).

Em 1926, nos poucos meses que frequentou o Parlamento, por ser afetado por uma grave doença, Domingos Pereira atuou como uma voz da consciência. Alertava sistematicamente para a "falta de entendimento dos homens públicos em Portugal", a "falta de acordo entre os partidos do regime em face dos grandes problemas nacionais, em face da necessidade de mudarmos de vida, de entrarmos num caminho que honre e prestigie a pátria e o regime" (DCD, 3.2.1926).

A crise política, contudo, não deixou de se acentuar. A inamovibilidade do PRP de António Maria da Silva, que pela quinta vez chefiava o Governo, remeteu definitivamente os grupos oposicionistas para soluções não constitucionais. $\mathrm{O}$ descontentamento generalizado, a questão dos tabacos, o escândalo de notas 
falsas de Alves dos Reis, a obstrução parlamentar contínua, a incapacidade de se gerar uma alternância ao partido dominante, tudo isto contribuiu para o desfecho anunciado, que se materializou no golpe de 28 de Maio de 1926, executado pelo Exército.

\section{Na resistência à Ditadura}

Domingos Pereira estava ainda doente e retirado da política quando se deu o golpe e se entrou numa Ditadura Militar, pela qual os dirigentes republicanos foram desapossados do poder. Só reapareceu em 1928, no prefácio que escreveu de um livro com discursos do ex-deputado católico Juvenal de Araújo; isso mostrava que mesmo fora do campo republicano era reconhecido o papel conciliador que desempenhara como presidente da Câmara dos Deputados. Nesse prefácio reconheceu os erros e o mau funcionamento do Parlamento, mas contestou que a solução fosse demoli-lo, como alguns reclamavam, antes devia ser o aperfeiçoamento da sua mecânica (Araújo 1928).

Alguns anos depois, numa entrevista incluída num livro publicado em 1932, A ditadura e os políticos, de Armando de Aguiar, tornou a reconhecer os erros passados, a desunião que atingira o máximo do absurdo, as divergências de opinião até ao excesso da luta de pessoas, e garantiu que os Republicanos estavam firmes na intenção de não repetir tais erros. Até aceitava uma Ditadura que representasse uma necessidade, por tempo limitado para resolver os males encontrados, embora lamentando que a atual Ditadura estivesse a prolongar-se e suprimisse qualquer discussão e discordância. A sua crítica maior, contudo, era que a Ditadura abrisse as fronteiras a caudilhos monárquicos e as fechasse a figuras da República, que deportasse inúmeros republicanos sem uma aparência de base que o justificasse, que demitisse dos seus lugares homens políticos da República para os substituir por monárquicos confessos; receava que os monárquicos tentassem uma restauração, como tinham tentado em 1919 (Monarquia do Norte).

Para futuro, enfim, Domingos Pereira esperava que os partidos políticos se reorganizassem para dar expressão às correntes de opinião (Aguiar 1932: 34-54). No entanto, o futuro não evoluiu bem como ele previa: não se confirmou o perigo monárquico, nem tão pouco os partidos voltaram a ser autorizados, nem os opositores deixaram de ser perseguidos. Também as dissensões entre os Republicanos não se atenuaram durante o combate ao regime ditatorial. Pelo contrário, continuavam bem patentes as querelas antigas.

Domingos Pereira, com o consenso e a cordialidade que sempre o caracterizaram, servia como um elo de ligação entre os vários grupos oposicionistas. As suas atividades valeram-lhe a expulsão do país, em 1935, e a demissão compulsiva do cargo de chefe da secretaria-geral da 5. ${ }^{a}$ Vara de Lisboa, que detinha desde 1911. 
Manteve-se sempre na oposição ao regime, sendo por diversas vezes detido e sujeito a interrogatório. Durante a II Guerra Mundial, esteve ligado ao Movimento Nacional de Unidade Antifascista (MUNAF). A partir de 1945, apoiou o Movimento de Unidade Democrática (MUD). Em 1949, foi um dos grandes apoiantes da candidatura presidencial de Norton de Matos. E continuou a apoiar todas as iniciativas da oposição moderada, como a Comissão Promotora do Voto e a Causa Republicana.

Quando Domingos Pereira faleceu, a 27 de Outubro de 1956, o jornal República colocou em grande destaque, na sua primeira página, que se tinha perdido um "republicano insigne, democrata eminente e cidadão integérrimo" (28.10.1956).

\section{Conclusão}

A partir de 1919, Domingos Leite Pereira foi uma das figuras mais interventivas da República, aquele que mais tempo ocupou funções governativas até 1926.

Como ministro, deputado e presidente da Câmara dos Deputados, Domingos Pereira pugnou sempre pela defesa do regime republicano; pela constitucionalização e legitimação parlamentar do sistema político; pela promoção de governos onde estivessem incluídas o maior número de correntes republicanas - se possível todas -, no sentido de uma maior responsabilidade governativa, também com o objetivo de neutralizar as naturais paixões políticas e as intensas lutas partidárias. A sua ação visava, em suma, captar para a República uma base alargada de apoio, que incluísse o mundo operário, sem exclusão dos sectores católicos, no sentido de uma cada vez mais ampla participação, legitimação e abrangência do sistema republicano.

Lutou também pela liderança do PRP, partido que verdadeiramente nunca conseguiu recuperar da ausência de Afonso Costa. Apesar de ser o maior partido do regime e de garantir sempre as vitórias eleitorais quando controlava o Ministério do Interior, frequentemente a divisão interna anulava a maioria parlamentar de que dispunha. Se a defesa de governos estáveis era uma das grandes linhas de força de Domingos Pereira, a luta pelo controlo do PRP revelou-se um dos maiores factores de turbulência do regime republicano. Em 1920 e 1921, quando a sua disputa com António Maria da Silva foi mais acesa, houve 14 governos, com uma duração média pouco superior a mês e meio.

Domingos Pereira não logrou alcançar a liderança do PRP nem conseguiu demonstrar as mesmas qualidades de um chefe político como Afonso Costa ou António Maria da Silva. Cunha Leal dizia dele que "tinha uma inteligência viva que lhe permitia compreender as causas profundas do mal-estar nacional", mas não era homem para as "grandes, para as decisivas decisões salvadoras e, ainda 
quando o fosse, não dispunha de autoridade e força para impô-las” (Leal 1967, II: 193). Segundo Ramada Curto, para quem as "qualidades de chefia" variavam com os "momentos históricos", "Domingos Pereira resignou-se a servir esse momento, que não foi nem brilhante nem forte por culpas que lhe eram estranhas"; "como uma sentinela isolada, posta num lugar perigoso, sabe que ocupa uma posição de sacrifício - mas fica e cumpre porque é o seu dever" ( $O$ Primeiro de Janeiro, 28.10.1956).

Por ter conduzido o regime até ser derrubado no golpe do 28 de Maio, a geração de Domingos Pereira sofreu um juízo severo de apreciação por parte dos historiadores. Disse Raul Rego que, em relação aos primeiros anos do regime, "baixou nitidamente a qualidade dos governantes" (Rego 1987, IV: 123). Oliveira Marques afirmou por sua vez que os resultados "cifraram-se por incompetência, caos administrativo, descontentamento generalizado" (Marques 1991: 727). Mas não se pode olvidar que foi esta geração que teve de enfrentar os enormes problemas que herdou da geração anterior, em especial os que resultaram da participação de Portugal na Guerra. Algo de semelhante aconteceu, aliás, em outros países europeus, na sequência da Grande Guerra, de tal modo que ocorreu então uma crise mais geral do liberalismo e da democracia.

Foi no papel de Presidente da Câmara dos Deputados que Domingos Pereira alcançou um consenso. Nesse cargo como relembrou Armando Marques Guedes soube manter a "disciplina, a ordem, a cordura, em termos de ser respeitado e acatado por todos os lados da Câmara, apesar da sua conhecida filiação partidária" (O Primeiro de Janeiro, 1.11.1956). Nas suas próprias palavras, Domingos Pereira referia que o seu "papel" consistia em "não ter opinião... É uma coisa mais difícil do que parece...” (Guimarães, Santos 1944: 37).

Esse espirito de isenção permitiu que, em 1925, num período fulcral da vida política portuguesa, se tornasse a única personagem a conseguir formar governo e realizar aquelas que seriam as últimas eleições da Primeira República. Esta capacidade de criar consensos, a procura de equilíbrios para conseguir agir e governar, mesmo nas maiores adversidades, acabaram por se tornar num dos seus maiores legados.

\section{Bibliografia}

\section{Periódicos:}

Diabo, (O). Lisboa, 1937

Diário da Câmara dos Deputados. Lisboa, 1911-1926

Diário do Senado. Lisboa, 1911-1926

Diário de Lisboa. Lisboa, 1921-1956

Mundo (O). Lisboa, 1906-1926 
Primeiro de Janeiro (O). Porto, 1910-1956

Rebate (O). Lisboa,1925

República. Lisboa, 1911-1956

Século (O). Lisboa, 1906-1956

Sol. Lisboa, 1949

\section{Monografias:}

AGUIAR, Armando, 1932 - A ditadura e os políticos. Lisboa: Hércules.

ARAÚJO, Juvenal de, (1928). Trabalhos Parlamentares. Funchal: Tip. Diário da Madeira

As Constituintes de 1911 e os seus deputados, (1911). Lisboa: Livr. Ferreira.

BAIÔA, Manuel, (2015). O Partido Republicano Nacionalista, 1923-1935: "Uma República para todos os portugueses”. Lisboa: ICS. Imprensa de Ciências Sociais

CHORÃO, Luís Bigotte, (2010). A Crise da República e a Ditadura Militar. Porto: Sextante Editora

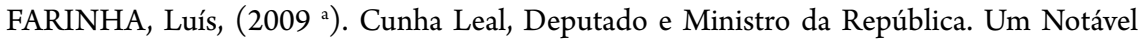
Rebelde. Lisboa: Assembleia da República / Texto Editores

FARINHA, Luís, $\left(2009^{\text {b}}\right.$ ). "A transformação política da República: o PRP dos 'bonzos', tempo dos deuses menores”, in Fernando Rosas e Maria Fernanda Rollo (eds.) História da Primeira República Portuguesa. Lisboa: Tinta da China, 463-484

FERREIRA, David, (1968). "Pereira, Domingos Leite” in Joel Serrão (ed.) Dicionário de História de Portugal, Lisboa, Iniciativas Editoriais, Vol. III, 354

Grande Enciclopédia Portuguesa e Brasileira, (s.d) Lisboa: Editorial Enciclopédia, vol. XXI

GUIMARÃES, Luís de Oliveira, Santos, José Ribeiro dos, (1944). Memórias dos outros. Lisboa: Marítimo Colonial.

JACA, Carlos, (Jul.- Dez. 2006) “Domingos Pereira, um bracarense na 1ª República: trajectória política” in Revista Fórum, 79-117.

LEAL, Cunha, (1926). Eu, os Políticos e a Nação. Lisboa: Portugal-Brasil.

LEAL, Francisco Cunha, (1967). As Minhas Memórias: coisas de tempos idos. Lisboa: Edição do Autor, II vol.

LEAL, Pedro Manuel Figueiredo, (2014). Domingos Leite Pereira: intervenção política e acção governativa durante a Primeira República. Universidade de Lisboa, Faculdade de Letras.

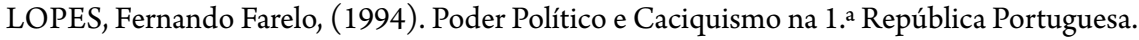
Editorial Estampa: Lisboa.

MARQUES, A.H. de Oliveira, (1981). Guia de História da 1a República Portuguesa. Lisboa: Estampa.

MARQUES, A.H. de Oliveira, (ed.), (1986). Dicionário de Maçonaria Portuguesa. Lisboa: Delta, vol. 2.

MARQUES, A. H. de Oliveira (ed.), (1991). Portugal da Monarquia para a República. Nova História de Portugal, Vol. 11, Lisboa: Editorial Presença. 
MARQUES, A. H. de Oliveira (ed.), (2000). Parlamentares e Ministros da 1. ${ }^{\text {a República. }}$ Porto: Edições Afrontamento/Assembleia da República.

MEDEIROS, Fernando, (1978). A sociedade e a economia portuguesas nas origens do salazarismo. Lisboa: A Regra do Jogo.

MENESES, Filipe Ribeiro de, (2004) 'O impacto da Primeira Guerra Mundial no sistema político português', in Manuel Baiôa (ed.), Elites e poder: A crise do sistema liberal em Portugal e Espanha (1918-1931). Lisboa: Edições Colibri, 421-446.

MENESES, Filipe Ribeiro de, (2010) Afonso Costa. Lisboa: Texto.

PÁBON, Jesus, (1951). A Revolução portuguesa. Lisboa: Aster.

PALACIOS CEREZALES, Diego, (2011). Portugal à coronhada: protesto popular e ordem pública nos séculos XIX e XX. Lisboa: Tinta-da-China.

PEREIRA, David Oliveira Ricardo, (2012). As Políticas Sociais em Portugal (1910-1926). Lisboa: Faculdade de Ciências Sociais e Humanas, Universidade Nova de Lisboa.

PERES, Damião, (1954). História de Portugal, Suplemento. Porto: Portucalense Editora.

PINTO, Ana Catarina, (2014). “Pereira, Domingos Leite (1882.1956) ” in Maria Fernanda Rollo (ed.) Dicionário de História da I República e do Republicanismo. Lisboa: Assembleia da República Vol. III, 244-246.

QUEIROZ, António José, (2008). A Esquerda Democrática e o final da Primeira República. Lisboa: Livros Horizonte.

SANTOS, António Pedro Ribeiro dos, (1999). O Estado e a ordem pública: as instituições militares portuguesas, Lisboa: Instituto Superior de Ciências Sociais e Políticas.

SILVA, João Manuel Garcia Salazar Gonçalves da, (1996). O Partido Reconstituinte: Clientelismo, faccionalismo e a descredibilização dos partidos políticos durante a Primeira República (1920-1923), tese de mestrado policopiada. Lisboa: Instituto de Ciências Sociais da Universidade de Lisboa.

REGO, Raul (1987). História da República. Lisboa: Círculo de Leitores, Vol. IV.

REIS, António, (1985). "Leite Pereira, Domingos” in Dicionário Ilustrado da História de Portugal, Lisboa: Pub. Alfa, Vol. I, 378.

SOUSA, Fernando de, Pereira, Conceição Meireles (eds.). (2012). Os Presidentes do Parlamento Português - vol. II, I República (1910-1926). Lisboa: Assembleia da República.

TEIXEIRA, Nuno Severiano, (1996). O poder e a guerra: 1914-1918: objectivos nacionais e estratégias políticas na entrada de Portugal na Grande Guerra, Lisboa: Estampa.

TELO, António José, (1980-1984). Decadência e Queda da I República Portuguesa. Lisboa: A Regra do Jogo, 2 volumes.

VENTURA, António, (2011). Constituintes de 1911 e a Maçonaria. Lisboa: Temas e Debates.

WHEELER, Douglas, (1985). História Política de Portugal de 1910 a 1926. Mem Martins: Europa-América.

VIEIRA, Alexandre (1950). Em volta da minha Profissão: Subsídios para a história do movimento operário no Portugal continental. Lisboa: Edição do autor.

XAVIER, Alberto, (1950). Memórias da vida pública. Lisboa: Livraria Ferin. 